\title{
Determinants of Entrepreneurship: Are Women Different?
}

\author{
Fernanda Llussá* \\ Faculdade de Ciências e Tecnologia \\ Universidade Nova de Lisboa
}

November 2010

\begin{abstract}
:
In this paper we investigate, for the first time, how individual determinants of entrepreneurship - such as age, income, education, work status, skills, access to networks and fear of failure - differ between males and females. We conduct our exercise using individual data provided by the Global Entrepreneurship Monitor (GEM), available for 46 countries, between 2001 and 2004. The literature on entrepreneurship has uncovered differences in the rate of entrepreneurship between men and women, with women generally displaying lower entrepreneurial activity than men. This is important since, as we show, entrepreneurial activity is positively related across countries with the female to male entrepreneurial ratio. We examine total entrepreneurship rates, as well as entrepreneurship driven by opportunity and by need. We find that indeed entrepreneurial activity rates are lower for females across all but one of the countries in the sample. Looking at categorical groups - by age interval, education, work status, etc. - we find that female entrepreneurial rates are significantly lower than for males. For the first time we test for differences in the characteristics of female and male entrepreneurs and find that female entrepreneurs are slightly older, more frequently at home or not working, lower income and lower educated, and less access to business networks than their male counterparts. AS to the determinants of entrepreneurial rates themselves, the main differences across genders are the lower impact of secondary education and the larger impact of skills and fear of failure in female entrepreneurial rates relative to males. Results for entrepreneurship by opportunity and by necessity confirm the larger importance of specific skills for women creating new businesses,. Our results suggest that facilitating access to business networks and specific business skills are the most powerful instruments to increase the rates of female entrepreneurship.
\end{abstract}

\footnotetext{
* I would like to thank Silvia Ardagna, José Mata, Stefan Mesiek, Antoinette Schoar and José Tavares for their comments and help with the data, and seminar participants at the European Academy of Management, the International Congress of Applied Economics, and the Massachussetts Institute of Technology (MIT) for their many suggestions. I also thank Fundação para a Ciência e Tecnologia for the financial support. All remaining errors are my own responsability. E-mail at fajl@fct.unl.pt.
} 


\section{Introduction}

A new and growing literature has uncovered the importance of personal characteristics as determinants of entrepreneurial activity. ${ }^{1}$ Characteristics such as education, personal income, work status and access to a network of entrepreneurs have been shown to affect the likelihood that any one person attempts to start a new business. A robust empirical fact receiving much less attention is the fact that, over time and across countries, entrepreneurship rates among women are about half those of males. ${ }^{2}$ Though discussed and noted by several authors, ${ }^{3}$ little has been done to explain what factors lie behind this important fact, including different personal characteristics, different returns to the characteristics and different goals when opening a business. ${ }^{4}$ Figures 1 and 2 below plot the entrepreneurship rate by country against the female to male entrepreneurship rate ratio. There is a clear positive relation between the two variables, so that countries where women are relatively less entrepreneurial are also countries where total entrepreneurial activity is lower. ${ }^{5}$ In other words, understanding the reasons why women are less frequently at the helm of new business ventures is a first step to devise policies that both help bridge the entrepreneurial gender gap as well as increase overall entrepreneurial activity. The latter is an important objective, as

\footnotetext{
${ }^{1}$ Notable examples are Ardagna and Lusardi (2008) and Djankov et al. (2006). There is no agreed to definition of entrepreneur. See Branco et al. (2008). Our task in the empirical exercise is facilitated by the use of a widely recognized data-set on intentions to start a business, the Global Entrepreneurship Monitor.

${ }^{2}$ Here we do not address the secular change in self-employment rates, as in Kuhn and Schuetze (2001), who finds that for women, most of the increase in self-employment is attributable to an increase in retention rates in self-employment, while for men, most is attributable to a decrease in the stability of paid employment.

${ }^{3}$ Ardagna and Lusardi (2008), for instance, use a male dummy indicator and find that males 1.1 percent higher probability of being an entrepreneur, for an average entrepreneurship arte of 5 percent.

${ }^{4}$ Cromie (1987) finds that both genders do have a variety of reasons for founding a business, primarily autonomy, achievement, a desire for job satisfaction and other non-economic rewards. The desire to make money, also present, is less important for women, who often choose entrepreneurship as a result of career dissatisfaction and as a means of meeting simultaneously their own career needs and the needs of their children.

${ }^{5}$ The simple correlation coefficient between the variables is 0.80 for total entrepreneurship and of 0.75 for entrepreneurship driven by opportunity, that is, intention to create a business that responds to a positive stimulus such as a new market opportunity, an innovation, etc.
} 
new firm creation is a major element in furthering economic growth and job creation. $^{6}$

This paper undertakes a cross-country study of the determinants of entrepreneurship with a view to answer three related questions: first, do female entrepreneurs differ from their male counterparts?; second, do the personal determinants of entrepreneurial activity differ between females and males?

An important issue related to our empirical study is whether women suffer from discrimination when planning to start a business. Discrimination at the workplace is an important subject of study and recent studies have uncovered discrimination in other areas, including in the key area of access to credit. ${ }^{7}$ Women receive less pay irrespective of their characteristics, as shown by the labor economics literature on gender discrimination. ${ }^{8}$ Though we discuss the possible discrimination against women that want to start a business, our focus is instead on the differential determinants of entrepreneurial activity by females. However, we recognize that entrepreneurship may be an effective antidote to discrimination based on prejudice and on employers' preferences, as it provides women with an autonomous avenue to circumvent social obstacles to employment, career progress and fair returns on effort.

Understanding the determinants of entrepreneurial activity by females is important also for policy reasons. First, increasing firm creation by females is a way to increase the productivity of the economy overcoming unnecessary barriers to women's labor force participation, initiative and talent; second, females may be more able and more interested than males in undertaking activities in areas that that are particularly innovative and beneficial for the economy. Our discussion is

\footnotetext{
${ }^{6}$ Entrepreneurship plays the vital role in the Schumpeterian process of "creative destruction" that fosters economic growth, innovation and employment.

${ }^{7}$ See Alesina et al. (2008) for an important study showing that, while women-led businesses are less prone to default, they have access to worse credit conditions than their male equivalent.

${ }^{8}$ See Cavalcanti and Tavares (2008) on the high aggregate output cost of gender discrimination.
} 
interesting in the context of the allocation of talent model, which see the stock of talent - for instance, among women - as relatively constant but its allocation towards a range of activities possibly subject to major changes in response to institutions and policies.' More specifically, in the study of entrepreneurship, several authors have suggested that, while the stock of entrepreneurs is relatively constant, the nature and social impact of their activities can change dramatically with country institutions. ${ }^{10}$

\section{Gender and Entrepreneurship: Data and Summary Statistics}

In this section we present the data on entrepreneurial activity across countries and over time, and relate it to individual characteristics of males and females.

\subsection{The Data}

In our empirical analysis we will draw on data from the Adult Population Surveys, collected by the Global Entrepreneurship Monitor (GEM). This data contain detailed information on individuals from 46 countries. W e can assess whether an individual is starting a new business, owns or manages a young firm, we can assess (at least partially) their motivation to start a firm, and take into account personal characteristics such as age, income, education, work status and skills. These micro survey data is collected annually and is made consistent across countries. ${ }^{11}$ In this paper we use yearly data from 2001 to $2004 .{ }^{12}$

\footnotetext{
${ }^{9}$ See Murphy et al. ??? (1991).

${ }^{10}$ See Baumol (1990). Niederle and Yestrumskas (2008) show that institutional design does affect the activity choices of women and men.

${ }^{11}$ Each year a sample of at least 2,000 randomly selected individuals in each country are surveyed by phone or through face-to-face interviews. On average, a total of 35 national experts in each country are responsible for conducting the surveys. A coordination team at London Business School supervises and checks for inconsistencies.

${ }^{12}$ This is the set of surveys available to researchers who not directly involved in the GEM project, and also those for which the methodology is most consistent across time.
} 
On the reliability of GEM data, Ardagna and Lusardi (2008) compare the GEM data with the Flash Eurobarometer Survey on Entrepreneurship collected by the European Commission for countries that are common to both data sets. ${ }^{13}$ The percentage of individuals involved in entrepreneurial activity is very similar in both datasets. The same is true for individuals pursuing a business opportunity or for whom entrepreneurship is for necessity. Results are also very similar when the authors compare individual characteristics such as age, sex and work status. ${ }^{14}$

Acs, Desai and Klapper (2007) compare GEM data to the World Bank Group datasets (WBEGS) which reports formal entrepreneurial activity as the number of newly registered firms of limited liability corporations (LLCs). From GEM data the authors compute the "nascent entrepreneurship rate" - share of individuals actively involved in starting a new venture - and "baby entrepreneurship rate" - share of people that are owners or managers of a business less than 42 months old. ${ }^{15}$ From the World Bank data, these authors compute the "corporate entrepreneurship rate" as the percentage of newly registered limited liability firms as a percentage of adult population. For the 41 countries examined between 2003 and 2005, Acs, Desai and Klapper (2007) find that GEM data tends to report significantly lower levels of early-stage that entrepreneurial activity in developed countries. Focusing on formal businesses, as WBEGS does, leads to the inclusion of initiatives that do not correspond to entrepreneurial activity, associated with legal incentives, in developed countries, to formally create new organizations. ${ }^{16}$ As GEM data computes the number of

${ }^{13}$ Countries surveyed in both data sets are: Belgium, Denmark, Finland, France, Germany, Hungary, Ireland, Italy, The Netherlands, Norway, Poland, Portugal, Slovenia, Spain, Sweden, United Kingdom and United States. See Ardagna and Lusardi (2008).

${ }^{14}$ The only exception is the percentage of individuals who think that fear of failing could prevent them from starting a new business, which is higher in the Flash Eurobarometer Survey $(47.5 \%)$ than in GEM data (33.3\%).

15 "Nascent" and "baby" entrepreneurship rates are two of the components of the Total Entrepreneurship Rate (TEA), the key variable in our study, as will become clear below.

${ }^{16}$ A couple of examples may illustrate this point. In Hong Kong all real estate sales, even those undertaken by individuals, are first converted to LLCs for tax reasons. In the United States firms may register several LLC's to limit liability in different lines of businesses. Shell companies formally register new business ventures for tax reasons, (see Acs et al. (2007)). In Italy, labor laws 
individuals entrepreneurs, it may overlook individuals that are involved in multiple businesses. Acs, Desai and Kappler (2007) confirm that GEM data reports higher rates of entrepreneurship for developing countries, which the authors explain by the importance of the informal sector, captured by GEM data.

Reynolds et al. (2005) compare GEM estimates on new firm's birth rate and national annual new firm's estimates with the Official New Firm Census and data from the European Commission Report. They show that TEA index as well as other indexes calculated using GEM data are reliable and consistent with other datasets.

A study like ours, interested in assessing how personal characteristics affect entrepreneurial rates, particularly how they differ across gender, would like a data set that covers the widest possible number of individuals, independently of whether in the formal or informal sector, and give less salience to formal and legal aspects. We thus consider that GEM data is the appropriate choice.

\subsection{Does Entrepreneurial Activity Differ Across Gender?}

Table 1 and Figure 4 present total entrepreneurship rates (TEA) in the male and female population, for a cross-section of countries. These are individuals who are either starting a new business or are owners or managers of a young firm. In addition to total entrepreneurial activity, we also report rates of entrepreneurial activity driven by opportunity (TEA OPP) and by need (TEA NEC). Individuals who claim they are starting a new business to take advantage of a business opportunity are

restricting hiring and firing of employees apply to firms with more than 15 employees, which is an incentive for business owners to register multiple smaller firms to lower the regulatory burden (see Kappler et all 2006). 
considered driven by opportunity; those that claim they could find no better job are classified as driven by necessity. ${ }^{17}$ TEA OPP and TEA NEC sum up to total entrepreneurial activity, TEA. Please note that in virtually all countries in the sample TEA rates for females are smaller that TEA rates for males. This is evident in the last column of Table 1 and in Figure 4, where we compute the female to male TEA rates. The single exception to the rule is Thailand, where this ratio is equal to one. The lowest female to male TEA ratio is that of Croatia which compares, at 0.33 , with the sample average of 0.53 . On average females display half of the entrepreneurial activity than males. This gender imbalance is even more pronounced for entrepreneurial activity driven by opportunity - TEA OPP, in columns (6) and (7) -, and less pronounced for entrepreneurial activity driven by need - columns (9) and (10) -, as summarized in the Column "All". In general low income countries display higher entrepreneurial activity rates, and more balanced between females and males. In poor countries, entrepreneurs are relatively more driven by need than opportunity. In sum, entrepreneurs are more likely to arise in poor countries, where they are also more likely to be females driven by necessity.

Figure 3 shows that women are less likely to be entrepreneurs than their male counterparts irrespective of age. The entrepreneurship rate attains it maximum between the ages of 25 and 35 years old, for both men and women. The average age at which females and males become entrepreneurs is around 38 years.

\footnotetext{
${ }^{17}$ Please consult Appendix I for more.
} 
Figures 5 and 6 display the age distribution of female and male entrepreneurs by motive. For both sexes and at all ages the opportunity motive is more prevalent than necessity. Women have lower rates but the rates of entrepreneurship by need, for females and males, are much closer than their equivalent for opportunity. Figures 7 and 8 show entrepreneurship rates by education and income levels, an important and clarifying exercise. Entrepreneurship rates increase with income and with education irrespective of gender. A closer look reveals that, while entrepreneurial activity driven by opportunity indeed rises with education and income, entrepreneurship by necessity behaves in the opposite fashion, decreasing with both income and education.

We now sharpen our question and try to answer whether female and male rates of entrepreneurial activity are different for a number of given characteristics. Our aim is to compute entrepreneurial rates by gender, for different ages groups, work status, education and income levels, social networks, etcetera. In Table 2 we present these different entrepreneurship rates and test whether the differences between females and males are statistically significant using the difference in means test. We reject the null hypothesis of equality of the female and male TEA and TEA OPP rates, at the 1\% confidence levels, for most cases.

In the case of entrepreneurial activity by need - TEA NEC - we can not reject the null hypothesis of equality for female and males who 
work at home, ${ }^{18}$ for individuals with same skills, or for countries that are classified as low or mid low income by the World Bank, or African countries in general. ${ }^{19}$ Taking these results at face value, the only sensible policies that would raise female entrepreneurship rates to the levels of their male counterparts would be to generalize access to specific business skills.

\subsection{Are Female and Male Entrepreneurs Different?}

In Table 3 we try to answer a different but key question. Instead of comparing entrepreneurial rates across gender, we compare the characteristics of female and male entrepreneurs and ask: are they different? We test whether those differences are statistically significant using difference in means test and the 1\% confidence level.

Table 3 shows that the average age of female and male entrepreneurs is very similar, at 38 years of age. Men that have a job have $8 \%$ higher probability of becoming entrepreneurs than women, $6 \%$ higher in the case of entrepreneurship by opportunity and $13 \%$ higher in the case of entrepreneurship by need. 5,2\% of women at home are entrepreneurs, compared to only $0,3 \%$ of men, and these numbers are similar for entrepreneurship by opportunity. Interestingly, $7.4 \%$ of women at home are entrepreneurs by need, compared with a

\footnotetext{
${ }^{18}$ Edwards and Field-Hendrey (2002) find that home-based work is an attractive option for women for whom the fixed costs of work are high-women who have small children, are disabled, or live in rural areas-and that home-based workers are more likely to choose self-employment than are on-site workers.

${ }^{19}$ See Appendix I for variables definition.
} 
paltry $0.2 \%$ for men. ${ }^{20}$ Among the individuals not working at the time of the interview, $10 \%$ of the females are entrepreneurs, compared to $7.5 \%$ of males. $1.5 \%$ of male students are entrepreneurs, which compares to $2 \%$ of female students, and this is true for entrepreneurship by need as well as by necessity. $22.6 \%$ of female individuals who report their income in the lowest $33^{\text {rd }}$ income percentile of the income distribution are entrepreneurs, as compared to $18 \%$ for males. The difference regarding entrepreneurs by need is even higher: at $31 \%$ for females, compared to $27 \%$ for males. The difference in means in the case of middle income is not statistically significant but it is in the case of upper income: $29.5 \%$ of males are entrepreneurs compared to $23 \%$ in the case of female. In terms of education there are almost no differences in gender probabilities of becoming an entrepreneur up to the college degree stage, when there are more women entrepreneurs. ${ }^{21}$ Finally, it is more frequent that male entrepreneurs know someone who has started a business in the recent past. $^{22}$ The variable "skills" is also more relevant in the case of men: $84 \%$ of male entrepreneurs say they think they have the knowledge, skills and experience to start a new business, compared to $78 \%$ for females. This is consistent with the fear of failure results: $23 \%$ of

\footnotetext{
${ }^{20}$ This result is consistent with Edwards and Field-Hendrey (2002) that using data from the 1990 Census, find that home-based work is an attractive option for women for whom the fixed costs of work are high. This is the case of women who have small children, are disabled, or live in rural areas-and that home-based workers are more likely to choose self-employment than are on-site workers.

${ }^{21}$ Vijverberg (1993) studies if women in the labor market enjoy the same returns to their human capital investments as men do and conclude that in Côte d'Ivoire, rates of return to education are high for both men and women, but men's wages exceed women's by a substantial margin for all but the most educated. Wong (1986) discusses the effect of spouse education on the productivity of entrepreneurial activity.

${ }^{22}$ Ibarra (1993) suggests that women have limited access to or are excluded from organizational networks and claims that the organizational context in which interaction networks are embedded produces unique constraints on women.
} 
female entrepreneurs compared to $19 \%$ of male entrepreneurs say that fear of failing can prevent them to start a new business. ${ }^{23}$

In sum, results in Table 3 show that female entrepreneurs are different as to whether they work - less do -, are at home - more do-, study - less do-, and whether they do not have a job - consistently, more female entrepreneurs are in this category. In addition, more female entrepreneurs are low income, when compared to males, and less are high income. No difference as to the gender incidence of entrepreneurship for middle income. Interestingly, using the income classification for countries, again women entrepreneurs are more frequent that their male counterparts in low to upper middle income countries and less so in high income countries. Also, female entrepreneurs are less connected to networks of entrepreneurs and are more fearful of being successful.

\section{Gender Specific Determinants of Entrepreneurial Activity}

We now formally analyze the individual determinants of gender activity and test how they differ across gender. Our dependent variables will be entrepreneurship rates- total, by opportunity and by need -, and our independent variables will include a host of individual characteristics, taken alone or interacted with a female indicator. For an individual $i$, in country $j$, at time $t$, we define the outcome of interest $y_{i j t}$ :as one of the

\footnotetext{
${ }^{23}$ Kalleberg and Leicht (1991) find that businesses headed by women were not more likely to go out of business, nor less successful, than those owned by men.
} 
three measures of entrepreneurial activity: TEA, TEA OPP and TEA NEC. We estimate the equation for $\mathrm{y}_{\mathrm{ijt}}$ :

$$
y_{i j t}=\alpha+\beta_{1} \cdot X_{i j t}+\beta_{2} \cdot X_{i j t} . \text { Female }_{i}+\gamma_{t}+\eta_{t}+\varepsilon_{i j t}
$$

where $\alpha$ is a constant, $\eta_{\mathrm{t}}$ a vector of country dummies and $\gamma_{\mathrm{t}}$ a vector of year dummies. $\mathrm{X}_{\mathrm{i} \mathrm{j}_{\mathrm{t}}}$ is our variable of interest, the vector of individual characteristics, including age, gender, employment status, education, income, the role of social networks, business skills, and fear of failure. ${ }^{24}$ This same vector appears the interacted with the gender indicator, Female $_{\mathrm{i}}$, which takes the value 1 when the individual is a woman. The coefficient on a variable such as "College", for instance, will give us the change in the probability of becoming an entrepreneur for an individual with the average characteristics in the sample. The variable "Female College" will give us the additional - positive or negative - effect on the probability of a female college graduate becoming and entrepreneur. Positive and significant coefficients on the variables interacted with the female indicator suggest females with that specific characteristic are more likely to be an entrepreneur that males with the same characteristic. The dependent variable is binary, and we use Probit estimation and correct the standard errors by clustering them at the country level. Our sample includes countries whose macroeconomic and institutional characteristics correlate both with the entrepreneurship indices. However, we control

\footnotetext{
${ }^{24}$ Ardagna and Lusardi (2008) estimate the probability of starting a business as a function of a set of demographic characteristics that are available in the data - age, gender, employment status, education, income, etc. - country by country for 2001 and 2002.
} 
for countries' specific characteristics by including country fixed effects to our specification.

Tables 4 and 5 present our results. In Table 4, for a totals of 424 566 observations, and for total entrepreneurship rates - TEA -, we obtain that entrepreneurial activity for females starts earlier in life but then also drops at a faster rate at older ages - see the positive and negative signs of Female.Age and Female.Age Squared. Secondary education is less of an incentive for entrepreneurship for females, as well as a graduate education. More importantly, skills boost female entrepreneurship beyond that of males. Interestingly, while fear tends to discourage male entrepreneurship, the opposite seems true for females, as attested by the negative, significant, and large coefficient on Female.Fear.

Different pattern of results emerge for TEA OPP and TEA NEC, but the few differences are worth noting. Now age does not affect differently males and females, except that younger females are more likely than their male counterparts to engage in entrepreneurship driven by opportunity, TEA OPP. Also, females at home are less likely to engage in entrepreneurship by opportunity, the same is true for female with graduate education. ${ }^{25}$ Female with entrepreneurial skills and that state they are fearful they might not be successful are more likely to be entrepreneurs, relative to their male counterparts. As to entrepreneurship

\footnotetext{
${ }^{25}$ Vijverberg (1993) finds that the return to education in self employment are high for both men and women, men's returns exceeding that of women's by a substantial margin for all but the most educated.
} 
by need, we find women who hold a job are significantly less likely to be entrepreneurs, as well as those that are students, that do not work. Again, we confirm that the existence of skills is even more important for females than for male entrepreneurs.

Notice that in all specification we have included a gender indicator, which is negative and significant for total entrepreneurial activity and for the subset of that activity that is driven by opportunity. For entrepreneurship by need, the female dummy does not capture significant differences between males and females, once the individuals characteristics and the interacted terms are taken into account.

Table 5 reruns the basic specification for countries that are classified as high income by the World Bank and fro the other, middle and low income countries. The third column introduces country dummies so that the specification is now: given by

$$
y_{i j t}=\alpha_{j}+\beta_{1} \cdot X_{i j t}+\beta_{2} \cdot X_{i j t} \cdot \text { Female }_{i}+\gamma_{t}+\varepsilon_{i j t}
$$

as in equation (1), except that $\alpha_{j}$ is a set of country dummies. For High income countries the main differences are that an individual with a job now increases his or her chance of becoming an entrepreneur, females at home are significantly less likely to be entrepreneurs, low income individuals are more likely to be entrepreneurs but that effect is not present for females ${ }^{26}$, and some graduate study increase the chance of

\footnotetext{
${ }^{26}$ As shown by the almost identical size and opposite signs of the coefficients on Low Income and Female.Low Income.
} 
being entrepreneurs for both male and female. For Low and Middle income countries age does differentiate entrepreneurial women and low income women indeed are les likely to be entrepreneurs. Fear of failure also does not distinguish female entrepreneurs. Interestingly, as was the case for entrepreneurship by need, the female dummy is not significantly different from zero.

\section{Conclusion}

This paper examines, for the first time, whether individual characteristics have a different impact on the likelihood of one becoming an entrepreneur, for males and females By examining total entrepreneurship rates, entrepreneurship driven by opportunity and by need, we find that indeed entrepreneurial activity rates are statistically and significantly lower for all categorical groups - by age interval, education, work status, network access, etc. -, except, in the case of entrepreneurship by need and the case of persons working at home, with specific entrepreneurial skills and that live in a middle or low income country.

We then estimate the differences in the personal characteristics of entrepreneurs across gender and find that female entrepreneurs are slightly older, more frequently at home or not working, lower income, lower educated, and with less access to specific skills than their male counterparts. As to the determinants of entrepreneurial rates themselves, the main differential impact across genders are the lower impact of secondary and graduate education, and the larger impact of skills and 
fear of failure in female entrepreneurial rates relative to males. Results for entrepreneurship by opportunity and by necessity confirm the larger importance of specific skills for women creating new businesses.

Combining the mean differences in male and female entrepreneurs' and the how they impact entrepreneurship rates, the main policy implication of our paper is that creating business networks accessible to females and imparting the specific business skills associated with entrepreneurship may be the most potent levers to increase female and total entrepreneurship across countries. 


\section{References}

[1] Acs Z., S. Desai, Klapper L., (2007), "What Does "Entrepreneurship" Data Really Show? A Comparison of the Global Entrepreneurship Monitor and World Bank Group Datasets."

[2] Alesina, Alberto, Lotti, Francesca, and Paolo Emilio Mistrulli (2008), "Do Women Pay More For Credit? Evidence from Italy", NBER Working Paper 14202.

[3] Alfaro L., A. Charlton, (2007), "International Financial Integration and Entrepreneurial Firm Dynamics", Harvard Business School Working Paper, n. 07012.

[4] Ardagna, Silvia and Annamaria Lusardi (2008). "Explaining International Differences in Entrepreneurship: The Role of Individual Characteristics and Regulatory Constraints", NBER Working Paper No. 14012.

[5] Bayoumi T., D. Laxton, P. Pesenti, (2004), "Benefits and Spillovers of Greater Competition in Europe: a Macroeconomic Assessment", Federal Reserve Bank of New York Staff Report 182.

[6] Barton H. Hamilton (2000). "Does Entrepreneurship Pay? An Empirical Analysis of the Returns of Self-Employment" The Journal of Political Economy, Vol. 108, No. 3, pp. 604-631.

[7] Bertrand, M. and F. Kramarz (2002). "Does Entry Regulation Hinder Job Creation? Evidence From The French Retail Industry." Quarterly Journal of Economics, November, 1369-1413.

[8] Blanchflower D., (2004), "Self-Employment: More May Not Be Better", Swedish Economic Policy Review, vol 11(2), Fall 2004, pp. 15-74.

[9] Blanchflower D., (2000), "Self-Employment in OECD Countries", Labour Economics, 7, September 2000, pp. 471-505.

[10] Blanchflower, David G. and Andrew J. Oswald (1998). "What Makes an Entrepreneur?”. Journal of Labor Economics, Vol. 16, No. 1 (Jan., 1998), pp. 2660.

[11] Blanchflower D., A. Oswald, and A.Stutzer, (2001), "Latent Entrepreneurship Across Nations", European Economic Review, 45(4-6) pp. 680-691, May 2001.

[12] Blanchflower D., A. Oswald, (1998), “What Makes an Entrepreneur?”, Journal of Labor Economics, January, 16(1) pp. 26-60, 1998. 
[13] Blanchard, O. J. and J. Wolfers (2000). "The Role of Shocks and Institutions in the Rise of European Unemployment: The Aggregate Evidence." Economic Journal, 110, 1-33.

[14] Bowen, Donald D. and Robert D. Hisrich (1986). "The Female Entrepreneur: A Career Development Perspective". The Academy of Management Review, Vol. 11, No. 2 pp. 393-407.

[15] Branco, Ruben, Llussá, Fernanda, and José Tavares (2008), "Entrepreneurship: Concepts and Measurement", Mimeo, Universidade Nova de Lisboa.

[16] Ciccone A., E. Papaioannou, (2006), "Red tape and Delayed Entry", CEPR Discussion Paper n 5996.

[17] Cole, Arthur H. (1942). "Entrepreneurship as an Area of Research". The Journal of Economic History, Vol. 2, Supplement: The Tasks of Economic History, pp. 118-126.

[18] Cromie, Stanley (1987). "Motivations of Aspiring Male and Female Entrepreneurs". Journal of Occupational Behaviour, Vol. 8, No. 3, pp. 251-261.

[19] Desai, M., P. Gompers and J. Lerner, (2003), "Institutions, Capital Constraints and Entrepreneurial Firm Dynamics: Evidence from Europe", NBER Working Paper No. 10165.

[20] Djankov S., T. Ganser, C. McLiesh, R. Ramalho, A. Shleifer, (2007), The Effect of Corporate Taxes on Investment and Entrepreneurship", unpublished.

[21] Djankov S., Y. Qian, G. Roland, and E. Zhuravskaya, (2006a), "Who are China's Entrepreneurs?", American Economic Review, Papers and Proceedings, vol. 96, May 2006, pp. 348-352.

[22] Djankov S., Y. Qian, G. Roland, and E. Zhuravskaya, (2006b), "Entrepreneurship in China and Russia Compared", Journal of the European Economic Association, vol. 4, n. 2-3, April-May 2006, pp. 352-365.

[23] Djankov S., Y. Qian, G. Roland, and E. Zhuravskaya, (2005), "Who are Russia's Entrepreneurs?", Journal of the European Economic Association, vol. 3, n. 2-3, April-May 2005, pp. 1-11.

[24] Djankov S., R. La Porta, Lopez-De-Silanes F., Shleifer A., (2002), "The Regulation of Entry", Quarterly Journal of Economics, February, pp. 1-37.

[25] Edwards, Linda N. and Elizabeth Field-Hendrey (2002). "Home-Based Work and Women's Labor Force Decisions". Journal of Labor Economics, Vol. 20, No. 1, pp. 170-200. 
[26] Evans D., B. Jovanovic, (1989), "An Estimated Model of Entrepreneurial Choice Under Liquidity Constraints", Journal of Political Economy, vol. 97, no. 4, pp. 808-827.

[27] Evans, David S. and Linda S. Leighton (1989). "Some Empirical Aspects of Entrepreneurship”.The American Economic Review, Vol. 79, No. 3 , pp. 519-535.

[28] Fairlie R., A. Robb, (2007), "Why Are Black-Owned Businesses Less Successful than White-Owned Businesses? The Role of Families, Inheritances, and Business Human Capital”, Journal of Labor Economics, 25(2): 289-323.

[29] Garcia, N. Chin, (2005), "Gobal Entrepreneurship Monitor: Data Collection Design and Implementation 1998-2003," Small Business Economics, vol. 24, pp. 205-231.

[30] Gentry W., R. G. Hubbard, (2000), "Tax Policy and Entrepreneurial Entry," American Economic Review Papers and Proceedings, vol. 90, no. 2, pp. 283 - 287.

[31] Guiso L., F. Schivardi, (2006), “What Determines Entrepreneurial Clusters?”. Mimeo.

[32] Guiso L., P. Sapienza, L. Zingales, (2004), "Does Local Financial Development Matter?”, Quarterly Journal of Economics, August, pp. 929-969.

[33] Harbury, C. D. and D. M. W. N. Hitchens (1977). "Women, Wealth and Inheritance”, The Economic Journal, Vol. 87, No. 345, pp. 124-131.

[34] Hundley, Greg (2000). "Male/Female Earnings Differences in SelfEmployment: The Effects of Marriage, Children, and the Household Division of Labor".Industrial and Labor Relations Review, Vol. 54, No. 1, pp. 95-114.

[35] Hurst E., A. Lusardi, (2004), "Liquidity Constraints, Household Wealth, and Entrepreneurship," Journal of Political Economy, April 2004, vol. 112(2), pp. 319347.

[36] Hurst E., A. Lusardi, (2008), "Liquidity Constraints and Entrepreneurship. Household Wealth, Parental Wealth, and the Transition In and Out of Entrepreneurship", forthcoming in "Overcoming Barriers to Entrepreneurship," Rowman and Littlefield.

[37] Ibarra, Herminia (1993) "Personal Networks of Women and Minorities in Management: A Conceptual Framework." The Academy of Management Review, Vol. 18, No. 1, pp. 56-87. 
[38] Kalleberg, Arne L. and Kevin T. Leicht (1991). "Gender and Organizational Performance: Determinants of Small Business Survival and Success". The Academy of Management Journal, Vol. 34, No. 1 pp. 136-161.

[39] Khan, B. Zorina (1996). "Married Women's Property Laws and Female Commercial Activity: Evidence from United States Patent Records, 1790-1895". The Journal of Economic History, Vol. 56, No. 2, Papers Presented at the FiftyFifth Annual Meeting of the Economic History Association, pp. 356-388

[40] Kehrer, Barbara H. (1976). "Factors Affecting the Incomes of Men and Women Physicians: An Exploratory Analysis". The Journal of Human Resources, Vol. 11, No. 4, pp. 526-545

[41] Klapper L., L. Laeven, and R. Rajan, (2006) ,"Entry Regulation as a Barrier to Entrepreneurship," Journal of Financial Economics (forthcoming).

[42] Kuhn, Peter J. and Herb J. Schuetze (2001). "Self-Employment Dynamics and Self-Employment Trends: A Study of Canadian Men and Women, 1982-1998". The Canadian Journal of Economics / Revue canadienne d'Economique, Vol. 34, No. 3 pp. $760-784$.

[43] La Porta R., F. Lopez-de-Silanes, A. Shleifer, R.W. Vishny, (2000), "Investor Protection and Corporate Governance," Journal of Financial Economics, vol. 58, pp. 1-25.

[44] Lounsbury, Michael and Mary Ann Glynn.(2001). "Cultural Entrepreneurship: Stories, Legitimacy, and the Acquisition of Resources." Strategic Management Journal, Vol. 22, No. 6/7, Special Issue: Strategic Entrepreneurship: Entrepreneurial Strategies for Wealth Creation, pp. 545-564.

[45] Morris, Michael H., Duane L. Davis and Jeffrey W. Allen.(1994) "Fostering Corporate Entrepreneurship: Cross-Cultural Comparisons of the Importance of Individualism versus Collectivism”. Journal of International Business Studies, Vol. 25, No. 1, pp. 65-89.

[46] Nanda R., and J. B. Sorensen, (2007), "Peer Effects and Entrepreneurship", Harvard Business School Working Paper n. 08-051.

[47] Niederle, Muriel, and Alexandra H. Yestrumskas (2008), "Gender Differences in Seeking Challenges: The Role of Institutions”, NBER Working Paper 13922.

[48] Papanek, Gustav F. (1962). “The Development of Entrepreneurship". The American Economic Review, Vol. 52, No. 2, Papers and Proceedings of the Seventy-Fourth Annual Meeting of the American Economic Association, pp. 4658. 
[49] Parasuraman, Saroj and Claire A. Simmers (2001). "Type of Employment, Work-Family Conflict and Well-Being: A Comparative Study". Journal of Organizational Behavior, Vol. 22, No. 5 (Aug., 2001), pp. 551-568.

[50] Puri M., D. T. Robinson, (2006), "Who Are Entrepreneurs and Why Do They Behave That Way", Working Paper Duke University. Reynonds P., N. Bosma, E. Autio, S. Hunt, N. De Bono, I. Servais, P. Lopez-

[51] Shane, Scott.(2000) "Prior Knowledge and the Discovery of Entrepreneurial Opportunities". Organization Science, Vol. 11, No. 4, pp. 448-469.

[52] Stewart, Alex.(1990) "The Bigman Metaphor for Entrepreneurship: A "Library Tale" with Morals on Alternatives for Further Research". Organization Science, Vol. 1, No. 2, pp. 143-159.

[53] van Praag, C. M. and J. S. Cramer (2001). "The Roots of Entrepreneurship and Labour Demand: Individual Ability and Low Risk Aversion".Economica, New Series, Vol. 68, No. 269, pp. 45-62.

[54] Vijverberg, Wim P. M. (1993). "Educational Investments and Returns for Women and Men in Côte d'Ivoire", The Journal of Human Resources, Vol. 28, No. 4, Special Issue: Symposium on Investments in Women's Human Capital and Development, pp. 933-974

[55] Wong, Yue-Chim (1986). "Entrepreneurship, Marriage, and Earnings". The Review of Economics and Statistics, Vol. 68, No. 4, pp. 693-699. 


\section{Appendix I}

\section{VARIABLE DEFINITON}

TEA $=1$ if individuals are starting a new business or are owners and managers of a young firm, 0 otherwise. Source: Global Entrepreneurship Monitor (GEM).

TEAOPP $=1$ if individuals are starting a new business or are owners and managers of a young firm to take advantage of a business opportunity, 0 otherwise. Entrepreneurship indices - source: Global Entrepreneurship Monitor (GEM).

TEANEC $=1$ if individuals are starting a new business or are owners and managers of a young firm because they could find no better economic work, 0 otherwise. Entrepreneurship indices source: Global Entrepreneurship Monitor (GEM).

AGE 14-20, AGE 21-25, AGE 26-35 etc.= age of individuals at the time of the interview categorized by range.

WORKING=individuals who work at the time of the interview.

RETIRED $=$ individuals who are retired at the time of the interview.

AT HOME $=$ individuals who work at home at the time of the interview. STUD $=$ individuals who are students at the time of the interview.

NOT WORKING=individuals who do not work at the time of the interview (and are not students, not retired, and do not work at home).

LOW INCOME=individuals who report that their income is in the lowest 33rd income percentile of their country's income distribution at the time of the interview.

MID INCOME = individuals who report that their income is in the middle 33rd income percentile of their country's income distribution at the time of the interview.

UP INCOME = individuals who report that their income is in the upper 33rd income percentile of their country's income distribution at the time of the interview.

HIGH SCHOOL $($ EDSEC) = only individuals with a high school degree.

COLLEGE (EDPSEC)= only individuals with a college degree.

GRADUATE (EDGRA) = only individuals with at least some graduate school education

KNOWS ENTREPRENEUR (KNOW) = individuals who know someone who has started a business in the recent past.

HAS SKILLS = individuals who think they have the knowledge, skills and experience to start a new business.

FEAR OF FAILURE = individuals who answer that fear of failing can prevent them to start a new business.

LOW INCOME WB (LOWINWB)= individuals who are interviewed at India and Uganda. 
MID LOW INCOME WB (MIDLOIWB) = individuals who are interviewed at China, Thailand, Chinese Shenzhen, Peru and Jordan.

UP MID INCOME WB (UPMIDIWB) = individuals who are interviewed at Argentina, Chile, Croatia, Hungary, Mexico, Poland, Russia, South Africa, Brazil, Venezuela.

HIGH INCOME WB (HIGHIWB) = individuals who are interviewed at Australia, Belgium, Canada, Denmark, Finland, France, Germany, Greece, Hong Kong, Iceland, Ireland, Israel, Italy, Japan, The Netherlands, Norway, New Zealand, Portugal, Scotland (UK), Singapore, Slovenia, Spain, South Korea, Sweden, Switzerland, Taiwan, United Kigdom and United States.

OECD = Australia,Belgium,Canada,Denmark, Finland, France, Germany, Greece, Iceland, Ireland,Italy, Japan, The Netherlands, Norway, New Zealand, Portugal, Scotland (UK), Spain, Swedeen, Switzerland, United Kingdom, United States.

$\mathrm{EU}=$ Belgium, Greece, Denmark, Finland, France, Germany, Iceland, Ireland, Italy, The Netherlands, Portugal, Scotland (UK), Spain, Sweden, United Kingdom.

ECA $=$ World bank classification-Europe \& Central Asia - Croatia, (Hungary), Poland, Russia, (Slovenia)-in parenthesis are not according to world bank classification.

EAP = World bank classification-East Asia \& Pacific - China, Hong Kong, Singapore, South Korea, (Taiwan), Thailand, (Chinese-Shenzhen)- in parenthesis are not according to world bank classification.

LATIN = World Bank classification Latin America - Argentina, Brazil, Chile, Mexico, Peru, Venezuela.

AFRICA $=$ World Bank classification Sub-Saharan Africa - South Africa, Uganda 


\section{Appendix II GEM QUESTIONNAIRE QUESTIONS}

The following are the questionnaires' questions that the GEM coordination team uses to generate the variables TEA, TEA OPP, TEA NEC. Questions are from the 2002 data documentation manual. Questions asked in 2001 were exactly the same, even though the numbering of the questions changes. The methodology followed to construct the indices is based on procedures previously used in the US Panel Study of Entrepreneurial Dynamics and it is described in detail in the 2001 and 2002 Adult Population Surveys' data documentation and in Reynolds et al. (2005).

1. Which of the following would apply to you? (Possible answers: Yes, No, Don't Know, Refused)

1a. You are, alone or with others, currently trying to start a new business, including any selfemployment or selling any goods or services to others.

1b. You are, alone or with others, currently trying to start a new business or a new venture for your employer- an effort that is part of your normal work.

1c. You are, alone or with others, currently the owner of a company you help manage, selfemployed, or selling any goods or services to others.

If "Yes", Or "Don't Know" To Qu. 1a or Qu. 1b, Ask Qu 2a. If "Yes", Or "Don't Know" To Qu. 1c, Ask Qu. 3a.

2a. Over the past twelve months have you done anything to help start a new business, such as looking for equipment or a location, organizing a start-up team, working on a business plan, beginning to save money, or any other activity that would help launch a business?

2b. Will you personally own all, part, or none of this business?

2d. Has the new business paid any salaries, wages, or payments in kind, including your own, for more than three months?

$2 \mathrm{~d} 1$. What was the first year the owners received wages, profits, or payments in kind?

$2 \mathrm{~g}$. Are you involved in this start-up to take advantage of a business opportunity or because you have no better choices for work?

3a. Do you personally own all, part, or none of this business?

$3 \mathrm{c}$. What was the first year the owners received wages, profits, or payments in kind? Payments in kind refers to goods or services provided as payments for work rather than cash.

3g. Are you involved in this firm to take advantage of a business opportunity or because you have no better choices for work.

The following are the questionnaires' questions used to define the variables Knowent, Skills, and Fear $f$ ail respectively. Questions are from the 2002 data documentation manual. Questions asked in 2001 were exactly the same even though the numbering of the questions changes.

1. Which of the following would apply to you? (Possible answers: Yes, No, Don't Know, Refused)

1g. You know someone personally who started a business in the past 2 years

$1 \mathrm{~h}$. In the next six months there will be good opportunities for starting a business in the area where you live

1i. You have the knowledge, skill and experience required to start a new business 1j. Fear of failure would prevent you from starting a business 
Table 1: Entrepreneurship Rate by Country

\begin{tabular}{|c|c|c|c|c|c|c|c|c|c|c|c|}
\hline & \multirow[t]{2}{*}{ N.Obs. } & \multicolumn{3}{|c|}{ TEA (\%) } & \multicolumn{3}{|c|}{ TEA OPP (\%) } & \multicolumn{3}{|c|}{ TEA NEC (\%) } & \multirow[t]{2}{*}{ TEA Fem/Male } \\
\hline & & All & Fem & Male & All & Fem & Male & All & Fem & Male & \\
\hline & (1) & (2) & (3) & (4) & (5) & (6) & (7) & (8) & (9) & $(10)$ & $(11)$ \\
\hline Argentina & 7998 & 12.77 & 9.18 & 16.58 & 7.54 & 4.64 & 10.62 & 4.69 & 4.10 & 5.31 & 0.55 \\
\hline Australia & 7661 & 7.68 & 6.00 & 10.10 & 6.13 & 4.81 & 8.05 & 1.16 & 0.82 & 1.66 & 0.59 \\
\hline Belgium & 12158 & 2.37 & 1.31 & 3.63 & 1.94 & 1.03 & 3.04 & 0.21 & 0.18 & 0.25 & 0.36 \\
\hline Brazil & 10000 & 12.05 & 10.01 & 14.01 & 6.18 & 4.83 & 7.47 & 5.52 & 4.92 & 6.10 & 0.71 \\
\hline Canada & 5944 & 6.12 & 3.99 & 8.24 & 4.86 & 3.08 & 6.63 & 0.98 & 0.68 & 1.27 & 0.48 \\
\hline Chile & 4008 & 13.37 & 10.75 & 16.05 & 7.58 & 5.53 & 9.69 & 5.09 & 4.69 & 5.50 & 0.67 \\
\hline China & 3661 & 11.69 & 8.97 & 14.61 & 6.28 & 4.01 & 8.72 & 5.11 & 4.59 & 5.66 & 0.61 \\
\hline Chinese Shenzhen & 2040 & 7.45 & 4.25 & 10.34 & 5.98 & 3.32 & 8.36 & 1.42 & 0.83 & 1.95 & 0.41 \\
\hline Croatia & 6017 & 2.49 & 1.31 & 3.99 & 1.50 & 0.68 & 2.52 & 0.71 & 0.45 & 1.05 & 0.33 \\
\hline Denmark & 8048 & 4.57 & 2.79 & 6.52 & 4.20 & 2.48 & 6.08 & 0.22 & 0.19 & 0.26 & 0.43 \\
\hline Finland & 8011 & 3.37 & 2.45 & 4.30 & 2.83 & 2.13 & 3.54 & 0.24 & 0.17 & 0.30 & 0.57 \\
\hline France & 7991 & 1.91 & 1.30 & 2.60 & 1.49 & 0.97 & 2.07 & 0.34 & 0.28 & 0.40 & 0.50 \\
\hline Germany & 37156 & 4.37 & 2.91 & 6.05 & 3.20 & 2.01 & 4.58 & 0.98 & 0.77 & 1.23 & 0.48 \\
\hline Greece & 4008 & 5.71 & 3.11 & 8.65 & 3.97 & 1.98 & 6.21 & 1.52 & 1.13 & 1.96 & 0.36 \\
\hline Hong Kong & 6004 & 2.43 & 1.47 & 3.52 & 1.60 & 0.94 & 2.34 & 0.82 & 0.50 & 1.17 & 0.42 \\
\hline Hungary & 6878 & 5.60 & 4.37 & 6.87 & 3.69 & 2.86 & 4.56 & 1.53 & 1.29 & 1.78 & 0.64 \\
\hline India & 5058 & 13.56 & 10.02 & 16.91 & 7.55 & 5.09 & 9.88 & 5.16 & 4.36 & 5.92 & 0.59 \\
\hline Iceland & 6013 & 9.00 & 6.27 & 11.82 & 7.47 & 5.19 & 9.82 & 0.63 & 0.39 & 0.88 & 0.53 \\
\hline Ireland & 7920 & 6.59 & 4.02 & 9.49 & 5.38 & 3.21 & 7.82 & 1.00 & 0.62 & 1.42 & 0.42 \\
\hline Israel & 5992 & 4.81 & 2.73 & 7.10 & 3.00 & 1.65 & 4.50 & 0.87 & 0.67 & 1.09 & 0.38 \\
\hline Italy & 8887 & 3.39 & 2.50 & 4.34 & 2.50 & 1.76 & 3.29 & 0.35 & 0.37 & 0.33 & 0.58 \\
\hline Japan & 7893 & 1.63 & 0.94 & 2.33 & 1.04 & 0.61 & 1.47 & 0.35 & 0.23 & 0.48 & 0.40 \\
\hline Jordania & 2000 & 19.10 & 13.70 & 23.12 & 15.20 & 10.66 & 18.59 & 2.85 & 1.76 & 3.66 & 0.59 \\
\hline Korea (South) & 4023 & 10.84 & 6.00 & 15.79 & 6.19 & 3.29 & 9.15 & 3.38 & 1.67 & 5.13 & 0.38 \\
\hline Mexico & 3016 & 16.15 & 14.13 & 19.92 & 10.51 & 8.59 & 14.11 & 4.97 & 5.03 & 4.86 & 0.71 \\
\hline Netherlands & 12535 & 3.18 & 1.95 & 4.79 & 2.77 & 1.74 & 4.12 & 0.26 & 0.11 & 0.44 & 0.41 \\
\hline New Zealand & 7848 & 11.53 & 9.31 & 14.53 & 9.57 & 7.72 & 12.07 & 1.67 & 1.30 & 2.16 & 0.64 \\
\hline Norway & 9833 & 5.55 & 3.06 & 8.14 & 4.75 & 2.48 & 7.10 & 0.41 & 0.24 & 0.58 & 0.38 \\
\hline Peru & 2007 & 39.61 & 38.60 & 40.68 & 26.31 & 24.93 & 27.77 & 12.95 & 13.19 & 12.70 & 0.95 \\
\hline Poland & 6001 & 5.48 & 3.58 & 7.44 & 3.25 & 1.94 & 4.60 & 2.13 & 1.54 & 2.74 & 0.48 \\
\hline Portugal & 3000 & 4.47 & 2.81 & 6.28 & 3.40 & 1.72 & 5.24 & 1.00 & 1.02 & 0.98 & 0.45 \\
\hline Russia & 2190 & 1.96 & 1.34 & 2.72 & 1.32 & 0.84 & 1.91 & 0.41 & 0.42 & 0.40 & 0.49 \\
\hline Scotland(UK) & 2118 & 2.64 & 1.67 & 3.76 & 2.12 & 1.23 & 3.15 & 0.47 & 0.35 & 0.61 & 0.44 \\
\hline Singapore & 9735 & 5.11 & 2.83 & 7.36 & 4.26 & 2.50 & 6.01 & 0.74 & 0.31 & 1.17 & 0.38 \\
\hline Slovenia & 6045 & 2.58 & 1.31 & 3.88 & 2.03 & 0.95 & 3.14 & 0.51 & 0.33 & 0.70 & 0.34 \\
\hline South Africa & 15519 & 5.39 & 4.23 & 6.54 & 3.36 & 2.44 & 4.28 & 1.61 & 1.52 & 1.70 & 0.65 \\
\hline Spain & 27996 & 5.37 & 3.11 & 7.59 & 4.51 & 2.64 & 6.37 & 0.75 & 0.41 & 1.09 & 0.41 \\
\hline Sweden & 32780 & 3.13 & 1.78 & 4.41 & 2.70 & 1.54 & 3.79 & 0.34 & 0.18 & 0.49 & 0.40 \\
\hline Switzerland & 4004 & 5.09 & 3.39 & 7.14 & 4.32 & 2.93 & 5.99 & 0.60 & 0.37 & 0.88 & 0.47 \\
\hline Taiwan & 2236 & 3.09 & 2.23 & 3.77 & 2.50 & 1.82 & 3.04 & 0.45 & 0.20 & 0.64 & 0.59 \\
\hline Thailand & 1043 & 20.04 & 20.06 & 20.00 & 16.01 & 16.30 & 15.56 & 3.16 & 3.13 & 3.21 & 1.00 \\
\hline Uganda & 3020 & 28.71 & 25.89 & 32.01 & 14.87 & 12.52 & 17.63 & 12.78 & 12.64 & 12.95 & 0.81 \\
\hline UK & 66434 & 4.07 & 2.66 & 5.99 & 3.31 & 2.16 & 4.87 & 0.60 & 0.38 & 0.91 & 0.44 \\
\hline US & 21056 & 8.57 & 6.17 & 11.07 & 6.98 & 4.95 & 9.10 & 1.03 & 0.81 & 1.26 & 0.56 \\
\hline Venezuela & 2000 & 23.55 & 21.7 & 25.4 & 13.15 & 10.80 & 15.50 & 9.45 & 10.00 & 8.90 & 0.85 \\
\hline All & 425785 & 5.92 & 4.17 & 7.88 & 4.32 & 2.91 & 5.90 & 1.32 & 1.06 & 1.61 & 0.53 \\
\hline Low Income WB & 8078 & 19.23 & 16.35 & 22.17 & 10.29 & 8.05 & 12.58 & 8.01 & 7.66 & 8.37 & 0.74 \\
\hline Mid Low Inc. WB & 10751 & 18.29 & 15.87 & 20.71 & 12.57 & 10.41 & 14.73 & 5.26 & 4.94 & 5.59 & 0.77 \\
\hline Up Mid Inc. WB & 63627 & 8.59 & 6.79 & 10.50 & 5.02 & 3.65 & 6.49 & 3.15 & 2.84 & 3.48 & 0.65 \\
\hline High Income WB & 343329 & 4.73 & 3.08 & 6.60 & 3.79 & 2.44 & 5.33 & 0.70 & 0.47 & 0.95 & 0.47 \\
\hline OECD & 309294 & 4.74 & 3.12 & 6.58 & 3.85 & 2.50 & 5.39 & 0.66 & 0.46 & 0.89 & 0.47 \\
\hline$\overline{E U}$ & 245055 & 4.13 & 2.61 & 5.87 & 3.35 & 2.08 & 4.81 & 0.59 & 0.40 & 0.81 & 0.44 \\
\hline ECA & 27131 & 3.92 & 2.56 & 5.40 & 2.55 & 1.56 & 3.62 & 1.16 & 0.86 & 1.49 & 0.47 \\
\hline EAP & 28742 & 6.74 & 4.58 & 8.95 & 4.64 & 3.08 & 6.25 & 1.80 & 1.25 & 2.35 & 0.51 \\
\hline Latin & 29029 & 15.55 & 13.16 & 18.13 & 9.07 & 7.14 & 11.15 & 5.96 & 5.58 & 6.37 & 0.73 \\
\hline Africa & 18539 & 9.19 & 8.00 & 10.40 & 5.24 & 4.19 & 6.31 & 3.43 & 3.46 & 3.41 & 0.77 \\
\hline
\end{tabular}

Notes: See Appendix I for exact variable definition. 
Table 2: Are Female Entrepreneurship Rate Different than Male?

\begin{tabular}{|c|c|c|c|c|c|c|c|c|c|}
\hline & \multicolumn{3}{|c|}{ TEA } & \multicolumn{3}{|c|}{ TEA OPP } & \multicolumn{3}{|c|}{ TEA NEC } \\
\hline & $\begin{array}{c}\text { Mean } \\
\text { Fem=1 }\end{array}$ & $\begin{array}{c}\text { Mean } \\
\text { Male=1 }\end{array}$ & $\begin{array}{l}\text { St.Error } \\
\text { of Diff }\end{array}$ & $\begin{array}{c}\text { Mean } \\
\text { Fem }=1\end{array}$ & $\begin{array}{c}\text { Mean } \\
\text { Male=1 }\end{array}$ & $\begin{array}{l}\text { St.Error } \\
\text { of Diff }\end{array}$ & $\begin{array}{c}\text { Mean } \\
\text { Fem }=1\end{array}$ & $\begin{array}{c}\text { Mean } \\
\text { Male }=1\end{array}$ & $\begin{array}{l}\text { St.Error } \\
\text { of Diff }\end{array}$ \\
\hline Age 14-20 & 0.0279 & 0.0512 & $0.0021 * * *$ & 0.0189 & 0.0355 & $0.0018^{* * *}$ & 0.0082 & 0.0135 & $0.0011 * * *$ \\
\hline Age 21-25 & 0.0520 & 0.0964 & $0.0027 * * *$ & 0.0357 & 0.0737 & $0.0023^{* * *}$ & 0.0139 & 0.0192 & $0.0013^{* * *}$ \\
\hline Age 26-35 & 0.0656 & 0.1216 & $0.0020^{* * *}$ & 0.0465 & 0.0933 & $0.0018^{* * *}$ & 0.0163 & 0.0225 & $0.0010^{* * * *}$ \\
\hline Age 36-45 & 0.0553 & 0.1018 & $0.0018^{* * *}$ & 0.0390 & 0.0767 & $0.0016^{* * *}$ & 0.0136 & 0.0208 & $0.0009 * * *$ \\
\hline Age 46-55 & 0.0393 & 0.0734 & $0.0017 * * *$ & 0.0268 & 0.0542 & $0.0014 * * *$ & 0.0103 & 0.0155 & $0.0008^{* * *}$ \\
\hline Age 56-65 & 0.0196 & 0.0429 & $0.0014^{* * *}$ & 0.0138 & 0.0300 & $0.0012^{* * *}$ & 0.0046 & 0.0101 & $0.0007 * * *$ \\
\hline Age old 65 & 0.0062 & 0.0157 & $0.0010^{* * *}$ & 0.0041 & 0.0113 & $0.0008^{* * *}$ & 0.0017 & 0.0031 & $0.0004 * * *$ \\
\hline Working & 0.0611 & 0.1009 & $0.0011 * * *$ & 0.0447 & 0.0774 & $0.0010^{* * *}$ & 0.0134 & 0.0190 & $0.0005^{* * *}$ \\
\hline Retired & 0.0069 & 0.0155 & $0.0010^{* * *}$ & 0.0042 & 0.0108 & $0.0009 * * *$ & 0.0020 & 0.0044 & $0.0006^{* * *}$ \\
\hline At Home & 0.0167 & 0.0370 & $0.0055^{* * *}$ & 0.0098 & 0.0295 & $0.0049 * * *$ & 0.0061 & 0.0051 & 0.0021 \\
\hline Student & 0.0148 & 0.0307 & $0.0021^{* * *}$ & 0.0113 & 0.0235 & $0.0018^{* * *}$ & 0.0029 & 0.0055 & $0.0009 * * *$ \\
\hline Not Working & 0.0258 & 0.0408 & $0.0014^{* * *}$ & 0.0152 & 0.0252 & $0.0011 * * *$ & 0.0095 & 0.0143 & $0.0009 * * *$ \\
\hline Low Income & 0.0337 & 0.0622 & $0.0013^{* * *}$ & 0.0202 & 0.0403 & $0.0011 * * *$ & 0.0119 & 0.0192 & $0.0008^{* * *}$ \\
\hline Middle Income. & 0.0415 & 0.0733 & $0.0014^{* * *}$ & 0.0298 & 0.0553 & $0.0012^{* * *}$ & 0.0097 & 0.0149 & $0.0007 * * *$ \\
\hline Up Income & 0.0568 & 0.1022 & $0.0018^{* * *}$ & 0.0460 & 0.0853 & $0.0017 * * *$ & 0.0079 & 0.0123 & $0.0007 * * *$ \\
\hline High School & 0.0341 & 0.0710 & $0.0012^{* * *}$ & 0.0242 & 0.0538 & $0.0011 * * *$ & 0.0081 & 0.0142 & $0.0006^{* * *}$ \\
\hline College & 0.0499 & 0.0950 & $0.0017 * * *$ & 0.0396 & 0.0768 & $0.0015^{* * *}$ & 0.0076 & 0.0130 & $0.0007 * * *$ \\
\hline Graduate & 0.0598 & 0.1049 & $0.0030 * * *$ & 0.0490 & 0.0892 & $0.0028 * * *$ & 0.0082 & 0.0115 & $0.0011 * * *$ \\
\hline Knows Entrepreneur & 0.0993 & 0.1495 & $0.0019 * * *$ & 0.0721 & 0.1147 & $0.0016^{* * *}$ & 0.0226 & 0.0276 & $0.0009 * * *$ \\
\hline Has Skills & 0.1206 & 0.1542 & $0.0018^{* * *}$ & 0.0862 & 0.1172 & $0.0016 * * *$ & 0.0289 & 0.0299 & 0.0009 \\
\hline Fear of failure & 0.0334 & 0.0594 & $0.0013^{* * *}$ & 0.0207 & 0.0403 & $0.0010^{* * *}$ & 0.0112 & 0.0163 & $0.0007^{* * *}$ \\
\hline Low Income WB & 0.1635 & 0.2217 & $0.0088^{* * *}$ & 0.0805 & 0.1258 & $0.0068^{* * *}$ & 0.0766 & 0.0837 & 0.0060 \\
\hline Mid Low Inc. WB & 0.1587 & 0.2071 & $0.0074 * * *$ & 0.1041 & 0.1473 & $0.0064 * * *$ & 0.0494 & 0.0559 & 0.0043 \\
\hline Up Mid Income WB & 0.0679 & 0.1050 & $0.0022^{* * *}$ & 0.0365 & 0.0649 & $0.0017 * * *$ & 0.0284 & 0.0348 & $0.0014 * * *$ \\
\hline High Income WB & 0.0308 & 0.066 & $0.0007 * * *$ & 0.0244 & 0.0533 & $0.0007 * * *$ & 0.0047 & 0.0095 & $0.0003^{* * *}$ \\
\hline OECD & 0.0312 & 0.0658 & $0.0008^{* * *}$ & 0.0250 & 0.0539 & $0.0007 * * *$ & 0.0046 & 0.0089 & $0.0003^{* * *}$ \\
\hline $\mathrm{EU}$ & 0.0261 & 0.0587 & $0.0008^{* * *}$ & 0.0208 & 0.0481 & $0.0007 * * *$ & 0.0040 & 0.0081 & $0.0003^{* * *}$ \\
\hline ECA & 0.0256 & 0.0540 & $0.0024 * * *$ & 0.0156 & 0.0362 & $0.0019 * * *$ & 0.0086 & 0.0149 & $0.0013^{* * *}$ \\
\hline EAP & 0.0458 & 0.0895 & $0.0030^{* * *}$ & 0.0308 & 0.0625 & $0.0025^{* * *}$ & 0.0125 & 0.0235 & $0.0016^{* * *}$ \\
\hline Latin A & 0.1316 & 0.1813 & $0.0043^{* * *}$ & 0.0714 & 0.1115 & $0.0034 * * *$ & 0.0558 & 0.0637 & $0.0028 * * *$ \\
\hline Africa & 0.0800 & 0.1040 & $0.0042^{* * *}$ & 0.0419 & 0.0631 & $0.0033 * * *$ & 0.0346 & 0.0341 & 0.0027 \\
\hline
\end{tabular}

Notes: Difference in means statististically different from zero at $1 \%(* * *)$. TEA $=$ Total Entrepreneurship Rate, TEA OPP = Entrepreneurship Rate by Opportunity and TEA NEC = Entrepreneurship Rate by Necessity. ECA = Europe and Central Asia. EAP = East Asia and Pacific. See Appendix for exact definition of the variables. 
Table 3 Are Women Entrepreneurs Different?

\begin{tabular}{|c|c|c|c|c|c|c|c|c|c|}
\hline & \multicolumn{3}{|c|}{ TEA } & \multicolumn{3}{|c|}{ TEA OPP } & \multicolumn{3}{|c|}{ TEA NEC } \\
\hline & $\begin{array}{c}\text { Mean } \\
\text { Fem=1 }\end{array}$ & $\begin{array}{c}\text { Mean } \\
\text { Male=1 }\end{array}$ & $\begin{array}{l}\text { St.Error } \\
\text { of Diff }\end{array}$ & $\begin{array}{c}\text { Mean } \\
\text { Fem=1 }\end{array}$ & $\begin{array}{c}\text { Mean } \\
\text { Male=1 }\end{array}$ & $\begin{array}{l}\text { St.Error } \\
\text { of Diff }\end{array}$ & $\begin{array}{c}\text { Mean } \\
\text { Fem }=1\end{array}$ & $\begin{array}{c}\text { Mean } \\
\text { Male=1 }\end{array}$ & $\begin{array}{l}\text { St.Error } \\
\text { of Diff }\end{array}$ \\
\hline Age & 38.144 & 37.879 & $0.1594^{*}$ & 38.109 & 37.697 & $0.1869 * *$ & 37.874 & 38.100 & 0.3349 \\
\hline Work & 0.7220 & 0.8096 & $0.0056^{* * *}$ & 0.7587 & 0.8292 & $0.0063^{* * *}$ & 0.6248 & 0.7464 & $0.0125^{* * *}$ \\
\hline Retir & 0.0166 & 0.0191 & 0.0017 & 0.0146 & 0.0177 & 0.0019 & 0.0185 & 0.0262 & $0.0039 *$ \\
\hline Home & 0519 & 0.0028 & $0.0023^{* * *}$ & 0.0437 & 0.0029 & $0.0026^{* * *}$ & 0.0742 & 0.0019 & $0.0054 * * *$ \\
\hline Stud & 0.0153 & 0.0196 & $0.0017 * * *$ & 0.0167 & 0.0200 & 0.0020 & 0.0118 & 0.0173 & $0.0032 *$ \\
\hline Nwork & 0.1039 & 0.0751 & $0.0038^{* * *}$ & 0.0875 & 0.0618 & $0.0041^{* * * *}$ & 0.1505 & 0.1287 & $0.0094 * *$ \\
\hline Lowinc & 0.2262 & 0.1819 & $0.0053^{* * *}$ & 0.1949 & 0.1573 & $0.0059 * * *$ & 0.3149 & 0.2749 & $0.0123^{* * *}$ \\
\hline Midinc & 0.2521 & 0.2514 & 0.0057 & 0.2600 & 0.2536 & 0.0067 & 0.2336 & 0.2505 & 0.0116 \\
\hline Upinc & 0.2319 & 0.2952 & $0.0057 * * *$ & 0.2700 & 0.3290 & $0.0070^{* * *}$ & 0.1269 & 0.1743 & $0.0095^{* * *}$ \\
\hline Lowinwb & 0.0714 & 0.0558 & $0.0032 * * *$ & 0.0504 & 0.0423 & $0.0033^{* *}$ & 0.1320 & 0.1031 & $0.0088^{* * *}$ \\
\hline Midloiwb & 0.0912 & 0.0701 & $0.0036^{* * *}$ & 0.0858 & 0.0666 & $0.0042^{* * *}$ & 0.1121 & 0.0926 & $0.0082^{* *}$ \\
\hline Upmidiwb & 0.2384 & 0.2036 & $0.0054 * * *$ & 0.1836 & 0.1681 & $0.0059 * * *$ & 0.3938 & 0.3305 & $0.0130 * * *$ \\
\hline Highiwb & 0.5990 & 0.6705 & $0.0063^{* * *}$ & 0.6802 & 0.7230 & $0.0071 * * *$ & 0.3621 & 0.4739 & $0.0132 * * *$ \\
\hline Edsec & 0.2749 & 0.2860 & $0.0058^{*}$ & 0.2800 & 0.2896 & 0.0069 & 0.2589 & 0.2792 & $0.0120^{*}$ \\
\hline Edpsec & 0.2523 & 0.2704 & $0.0057 * * *$ & 0.2873 & 0.2920 & 0.0070 & 0.1522 & 0.1805 & $0.0100 * * *$ \\
\hline Edgra & 0.1050 & 0.1073 & 0.0040 & 0.1234 & 0.1218 & 0.0051 & 0.0565 & 0.0574 & 0.0063 \\
\hline Know & 0.5789 & 0.6666 & $0.0063^{* * *}$ & 0.6030 & 0.6834 & $0.0074 * * *$ & 0.5198 & 0.6029 & $0.0134 * * *$ \\
\hline Skills & 0.7873 & 0.8481 & $0.0051^{* * *}$ & 0.8069 & 0.8612 & $0.0058^{* * * *}$ & 0.7441 & 0.8047 & $0.0113^{* * *}$ \\
\hline Fear & 0.2337 & 0.1920 & $0.0054 * * *$ & 0.2076 & 0.1740 & $0.0061 * * *$ & 0.3082 & 0.2579 & $0.0122 * * *$ \\
\hline
\end{tabular}

Notes: Difference in means statististically different from zero at $1 \%(* * *), 5 \%\left(^{(* *}\right)$ and $10 \%\left(^{*}\right)$. TEA $=$ Total Entrepreneurship Rate, TEA OPP $=$ Entrepreneurship Rate by Opportunity and TEA NEC= Entrepreneurship Rate by Necessity. See Appendix for the exact definition of the variables. 
Table 4 Probit - Determinants of Entrepreneurship

\begin{tabular}{|c|c|c|c|}
\hline \multirow[t]{2}{*}{ Dependent Variable: } & TEA & TEA OPP & TEA NEC \\
\hline & $(1)$ & $(2)$ & (3) \\
\hline \multirow[t]{2}{*}{ Age } & $0.0012811(* * *)$ & $0.0007071(* *)$ & $0.0004609(* * *)$ \\
\hline & $(0.000396)$ & $(0.0002893)$ & $(0.0001132)$ \\
\hline \multirow[t]{2}{*}{ Age Squared } & $-0.0000248(* * *)$ & $-0.000015(* * *)$ & $-0.00000733(* * *)$ \\
\hline & $(0.000005)$ & $(0.00000353)$ & $(0.00000139)$ \\
\hline \multirow[t]{2}{*}{ Female.Age } & $0.0007036(* *)$ & $0.0004696(*)$ & 0.000111 \\
\hline & $(0.0003281)$ & $(0.0002692)$ & $(0.0001226)$ \\
\hline \multirow[t]{2}{*}{ Female.Age Squared } & $-0.000007\left(^{*}\right)$ & $-4.54 \mathrm{e}-06$ & -0.174000 \\
\hline & $(0.000004)$ & $(0.00000319)$ & $(0.00000146)$ \\
\hline \multirow[t]{2}{*}{ Working } & 0.0076458 & 0.0057601 & 0.0011893 \\
\hline & $(0.0060855)$ & $(0.0038491)$ & $(0.0018578)$ \\
\hline \multirow[t]{2}{*}{ Female.Working } & -0.0022279 & 0.0003538 & $-0.0020516(* *)$ \\
\hline & $(0.0021099)$ & $(0.0015014)$ & $(0.0009416)$ \\
\hline \multirow[t]{2}{*}{ At Home } & -0.0042308 & 0.0011817 & -0.0044772 \\
\hline & $(0.0098782)$ & $(0.0086039)$ & $(0.0027565)$ \\
\hline \multirow[t]{2}{*}{ Female.At Home } & -0.0134579 & $-0.0109482(*)$ & 0.0010409 \\
\hline & $(0.0073586)$ & $(0.0046752)$ & $(0.0051682)$ \\
\hline \multirow[t]{2}{*}{ Student } & $-0.0175774(* * *)$ & $-0.0108275(* * *)$ & $-0.0044322(* *)$ \\
\hline & $(0.004828)$ & $(0.0029325)$ & $(0.0017395)$ \\
\hline \multirow[t]{2}{*}{ Female.Student } & -0.0056529 & -0.0008879 & $-0.003522(* *)$ \\
\hline & (0.0040784) & $(0.0031686)$ & $(0.0011993)$ \\
\hline \multirow[t]{2}{*}{ Not Working } & -0.0074277 & $-0.0070455(* *)$ & 0.0015583 \\
\hline & $(0.0056668)$ & $(0.0030436)$ & $(0.0026615)$ \\
\hline \multirow[t]{2}{*}{ Female.Not Working } & -0.0012184 & 0.0011949 & $-0.0024747(* * *)$ \\
\hline & $(0.0028817)$ & $(0.0020342)$ & $(0.0009146)$ \\
\hline \multirow{2}{*}{ Low Income } & 0.0018601 & -0.0016818 & $0.0032337(* * *)$ \\
\hline & $(0.0023676)$ & $(0.0015527)$ & $(0.0011427)$ \\
\hline \multirow[t]{2}{*}{ Female.Low Income } & 0.00051 & 0.0002493 & -0.0001898 \\
\hline & $(0.0015955)$ & $(0.0012306)$ & $(0.0004905)$ \\
\hline \multirow[t]{2}{*}{ Upper Income } & 0.0004073 & $0.0031265(* *)$ & $-0.0034215(* * *)$ \\
\hline & $(0.0020432)$ & $(0.001402)$ & $(0.0010048)$ \\
\hline \multirow[t]{2}{*}{ Female.Upper Income } & -0.0019611 & -0.0010211 & -0.0004877 \\
\hline & $(0.0014898)$ & $(0.0010019)$ & $(0.0008291)$ \\
\hline \multirow[t]{2}{*}{ Secondary Education } & $-0.0043625(* *)$ & -0.0016939 & $-0.001841(* * *)$ \\
\hline & $(0.0019644)$ & $(0.0011623)$ & $(0.0008013)$ \\
\hline Female. Secondary Education & $-0.002201\left(^{*}\right)$ & -0.0010864 & -0.0009289 \\
\hline & $(0.0011981)$ & $(0.0009371)$ & $(0.0006421)$ \\
\hline Graduate Education & 0.0042906 & $0.0058832(* * *)$ & $-0.0030409(* *)$ \\
\hline & $(0.0029192)$ & $(0.001745)$ & $(0.0012842)$ \\
\hline Female.Graduate Education & $-0.00491(* *)$ & $-0.0029503(* *)$ & -0.0007536 \\
\hline & $(0.0019009)$ & $(0.0011753)$ & $(0.0008394)$ \\
\hline Access to Network & $0.0325205(* * *)$ & $0.0222001(* * *)$ & $0.0051558(* * *)$ \\
\hline & $(0.0048195)$ & $(0.0031912)$ & $(0.0012469)$ \\
\hline Female.Access to Network & -0.0004686 & 0.0001596 & 0.0002834 \\
\hline & $(0.0011939)$ & $(0.0007552)$ & $(0.0005956)$ \\
\hline Skills & $0.0754828(* * *)$ & $0.0521001(* * *)$ & $0.0153624(* * *)$ \\
\hline & $(0.006847)$ & $(0.0043116)$ & $(0.0027961)$ \\
\hline Female.Skills & $0.0045518(* * *)$ & $0.0028749(* * *)$ & $0.0022702(* *)$ \\
\hline & $(0.0018929)$ & $(0.0011066)$ & $(0.0011687)$ \\
\hline Fear of Failure & $-0.0124748(* * *)$ & $-0.0101741(* * *)$ & -0.000039 \\
\hline & $(0.001688)$ & $(0.001107)$ & $(0.0006989)$ \\
\hline Female.Fear of Failure & $0.0037597(* * *)$ & $0.0019234(* *)$ & 0.0005197 \\
\hline & $(0.0010835)$ & $(0.0009526)$ & $(0.0003831)$ \\
\hline Female Dummy & $-0.022924(* * *)$ & $-0.0187569(* * *)$ & -0.0013471 \\
\hline & $(0.007935)$ & $(0.006515)$ & $(0.001992)$ \\
\hline Number of Observations & 424566 & 424566 & 424566 \\
\hline Log pseudo likelihood & -77333.3 & -61098.6 & -26589.2 \\
\hline
\end{tabular}

Note: Significant at 1\%(***);5\%(**) and 10\% (*). Standard errors adjusted for clustering on country. Year dummies not reported for parsimony reasons. 
Table 5 Probit - High, Middle and Low Income, With Country Dummies

\begin{tabular}{|c|c|c|c|}
\hline Dependent Variable: & $\begin{array}{l}\text { TEA if } \\
\text { High Income } \\
\text { Country }\end{array}$ & $\begin{array}{c}\text { TEA if } \\
\text { Not High Income } \\
\text { Country }\end{array}$ & $\begin{array}{c}\text { TEA } \\
\text { With country } \\
\text { dummy }\end{array}$ \\
\hline & (1) & (2) & (3) \\
\hline Age & $\begin{array}{c}0.0010058(* * *) \\
(0.0003375)\end{array}$ & $\begin{array}{c}0.002179(* *) \\
(0.0009658)\end{array}$ & $\begin{array}{c}0.0011555(* * *) \\
(0.0002931)\end{array}$ \\
\hline Age Squared & $\begin{array}{c}-0.0000178(* * *) \\
(0.00000375)\end{array}$ & $\begin{array}{c}-0.0000437(* * *) \\
(0.0000118)\end{array}$ & $\begin{array}{c}-0.0000206(* * *) \\
(0.00000335)\end{array}$ \\
\hline Female.Age & $\begin{array}{c}0.0010298(* * *) \\
(0.0002942)\end{array}$ & $\begin{array}{c}0.0004601 \\
(0.0007182)\end{array}$ & $\begin{array}{c}0.0007871(* * *) \\
(0.000277)\end{array}$ \\
\hline Female.Age Squared & $\begin{array}{c}-0.0000103(* * *) \\
(0.00000344)\end{array}$ & $\begin{array}{l}-0.00000385 \\
(0.00000849)\end{array}$ & $\begin{array}{c}-0.00000812(* *) \\
(0.00000332)\end{array}$ \\
\hline Working & $\begin{array}{c}0.0099294(* * *) \\
(0.0032134)\end{array}$ & $\begin{array}{c}0.0278687 \\
(0.0191623)\end{array}$ & $\begin{array}{c}0.0138492(* * *) \\
(0.0024626)\end{array}$ \\
\hline Female.Working & $\begin{array}{l}-0.0002121 \\
(0.0012289)\end{array}$ & $\begin{array}{c}0.0069066 \\
(0.0067294)\end{array}$ & $\begin{array}{l}-0.0005118 \\
(0.0014188)\end{array}$ \\
\hline At Home & $\begin{array}{c}0.0038664 \\
(0.0099792)\end{array}$ & $\begin{array}{l}-0.0108563 \\
(0.0259339)\end{array}$ & $\begin{array}{l}0.0063047 \\
(0.007768)\end{array}$ \\
\hline Female.At Home & $\begin{array}{c}-0.0126125\left(^{*}\right) \\
(0.0047583)\end{array}$ & $\begin{array}{l}-0.0244354 \\
(0.0193017)\end{array}$ & $\begin{array}{c}-0.0168033(* * *) \\
(0.0033363)\end{array}$ \\
\hline Student & $\begin{array}{c}-0.0083534(* *) \\
(0.0035513)\end{array}$ & $\begin{array}{c}-0.0461429(* * *) \\
(0.016008)\end{array}$ & $\begin{array}{c}-0.011673(* * *) \\
(0.0032002)\end{array}$ \\
\hline Female.Student & $\begin{array}{l}-0.0033981 \\
(0.0039441)\end{array}$ & $\begin{array}{l}-0.0044515 \\
(0.0127087)\end{array}$ & $\begin{array}{l}-0.0046466 \\
(0.0032096)\end{array}$ \\
\hline Not Working & $\begin{array}{l}-0.002405 \\
(0.0039859)\end{array}$ & $\begin{array}{l}-0.0128382 \\
(0.0180596)\end{array}$ & $\begin{array}{l}-0.0007438 \\
(0.0033046)\end{array}$ \\
\hline Female.Not Working & $\begin{array}{c}0.0010477 \\
(0.0023035)\end{array}$ & $\begin{array}{l}-0.0048955 \\
(0.006536)\end{array}$ & $\begin{array}{l}-0.0013213 \\
(0.0018664)\end{array}$ \\
\hline Low Income & $\begin{array}{c}0.0024392(*) \\
(0.001275)\end{array}$ & $\begin{array}{l}-0.0134449 \\
(0.0090946)\end{array}$ & $\begin{array}{l}-0.0008159 \\
(0.0016588)\end{array}$ \\
\hline Female.Low Income & $\begin{array}{c}-0.0018494(* *) \\
(0.0008563)\end{array}$ & $\begin{array}{c}0.0100232(* *) \\
(0.0062816)\end{array}$ & $\begin{array}{c}0.0006914 \\
(0.0013198)\end{array}$ \\
\hline Upper Income & $\begin{array}{c}0.0020413 \\
(0.0015904)\end{array}$ & $\begin{array}{l}-0.0081072 \\
(0.0069403)\end{array}$ & $\begin{array}{c}0.0024229(*) \\
(0.0013375)\end{array}$ \\
\hline Female.Upper Income & $\begin{array}{l}-0.0019223 \\
(0.0013442)\end{array}$ & $\begin{array}{c}0.0029284 \\
(0.0045783)\end{array}$ & $\begin{array}{l}-0.0014872 \\
(0.0012768)\end{array}$ \\
\hline Secondary Education & $\begin{array}{l}-0.000431 \\
(0.0010276)\end{array}$ & $\begin{array}{c}-0.0170448(* * *) \\
(0.0057334)\end{array}$ & $\begin{array}{c}0.0000294 \\
(0.0008396)\end{array}$ \\
\hline Female. Secondary Education & $\begin{array}{l}-0.0004096 \\
(0.0007992)\end{array}$ & $\begin{array}{l}-0.0021769 \\
(0.0048668)\end{array}$ & $\begin{array}{l}-0.0002917 \\
(0.0009337)\end{array}$ \\
\hline Graduate Education & $\begin{array}{c}0.0061239(* * *) \\
(0.0015423)\end{array}$ & $\begin{array}{c}0.000362 \\
(0.012995)\end{array}$ & $\begin{array}{c}0.00455(* * *) \\
(0.001507)\end{array}$ \\
\hline Female.Graduate Education & $\begin{array}{l}-0.0016214 \\
(0.0014744)\end{array}$ & $\begin{array}{c}-0.0146482(* *) \\
(0.0059412)\end{array}$ & $\begin{array}{c}-0.0030858(* *) \\
(0.0014739)\end{array}$ \\
\hline Access to Network & $\begin{array}{c}0.0266864(* * *) \\
(0.0047317)\end{array}$ & $\begin{array}{c}0.0485451(* * *) \\
(0.0086378)\end{array}$ & $\begin{array}{c}0.0294661(* * *) \\
(0.0019402)\end{array}$ \\
\hline Female.Access to Network & $\begin{array}{l}-0.0006732 \\
(0.0009054)\end{array}$ & $\begin{array}{l}-0.000071 \\
(0.0050795)\end{array}$ & $\begin{array}{l}-0.0011524 \\
(0.0009255)\end{array}$ \\
\hline Skills & $\begin{array}{c}0.061087(* * *) \\
(0.0064087)\end{array}$ & $\begin{array}{c}0.1182471(* * *) \\
(0.0115175)\end{array}$ & $\begin{array}{c}0.0639777(* * *) \\
(0.0026207)\end{array}$ \\
\hline Female.Skills & $\begin{array}{c}0.0019328\left(^{*}\right) \\
(0.0010596)\end{array}$ & $\begin{array}{c}0.0128501(* *) \\
(0.0069365)\end{array}$ & $\begin{array}{c}0.0023726(* *) \\
(0.001137)\end{array}$ \\
\hline Fear of Failure & $\begin{array}{c}-0.0093896(* * *) \\
(0.0008314)\end{array}$ & $\begin{array}{c}-0.0220796(* * *) \\
(0.0070753)\end{array}$ & $\begin{array}{c}-0.0113851(* * *) \\
(0.0013204)\end{array}$ \\
\hline Female.Fear of Failure & $\begin{array}{c}0.0034975(* * *) \\
(0.0008805)\end{array}$ & $\begin{array}{c}0.0040806 \\
(0.0036144)\end{array}$ & $\begin{array}{c}0.0039459(* * *) \\
(0.0008916)\end{array}$ \\
\hline Female Dummy & $\begin{array}{c}-0.0335328(* * *) \\
(0.007826)\end{array}$ & $\begin{array}{c}-0.026891 \\
(0.0181669)\end{array}$ & $\begin{array}{c}-0.0256169(* * *) \\
(0.0063351)\end{array}$ \\
\hline N. obs & 342129 & 82437 & 424566 \\
\hline Log pseudo likelihood & -51982.627 & -23662.101 & -73615.532 \\
\hline
\end{tabular}

Note: Significant at $1 \%(* * *) ; 5 \%(* *)$ and $10 \%(*)$. Standard errors adjusted for clustering on country. Country dummies and year dummies not reported for parsimony reasons. 

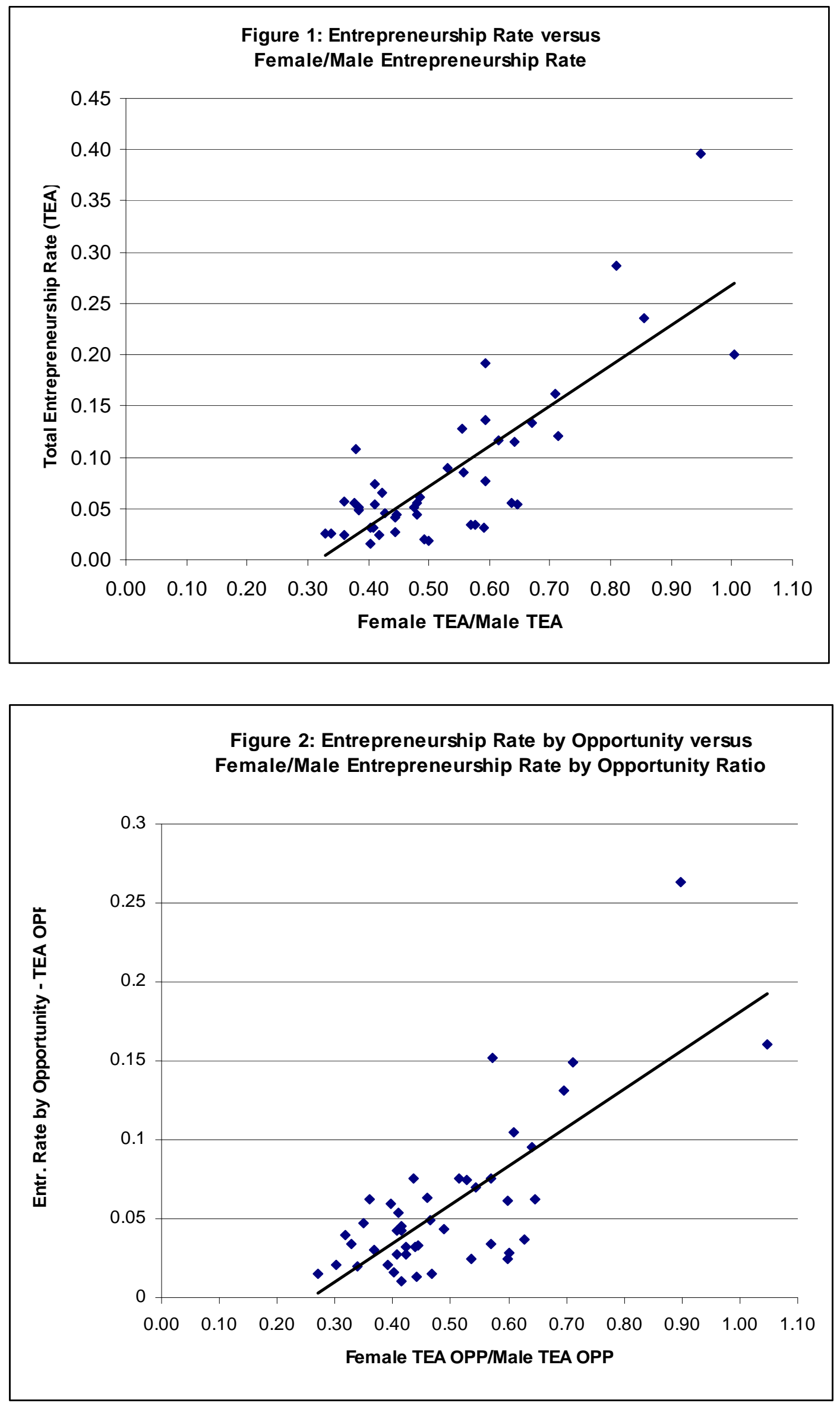


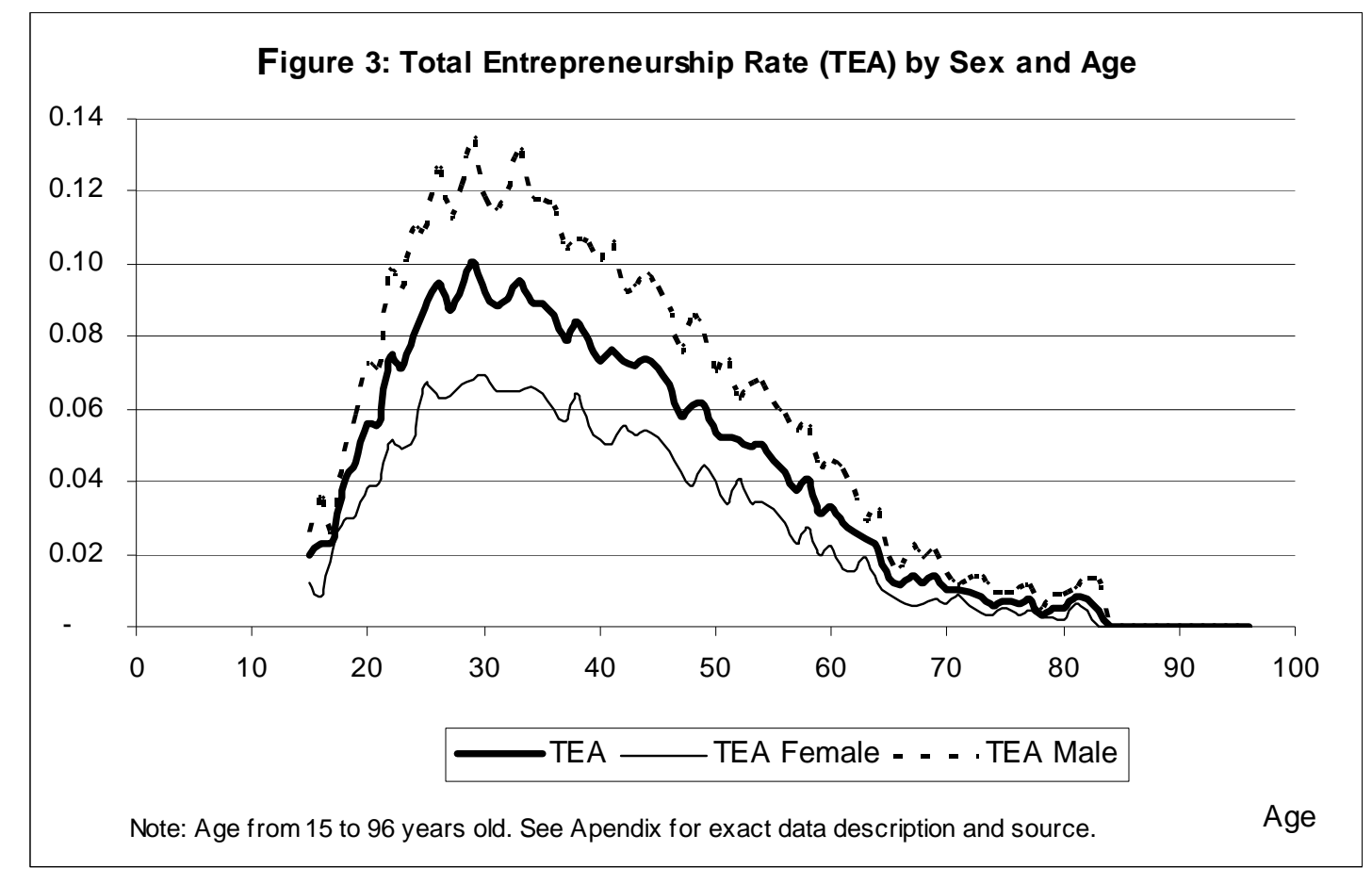




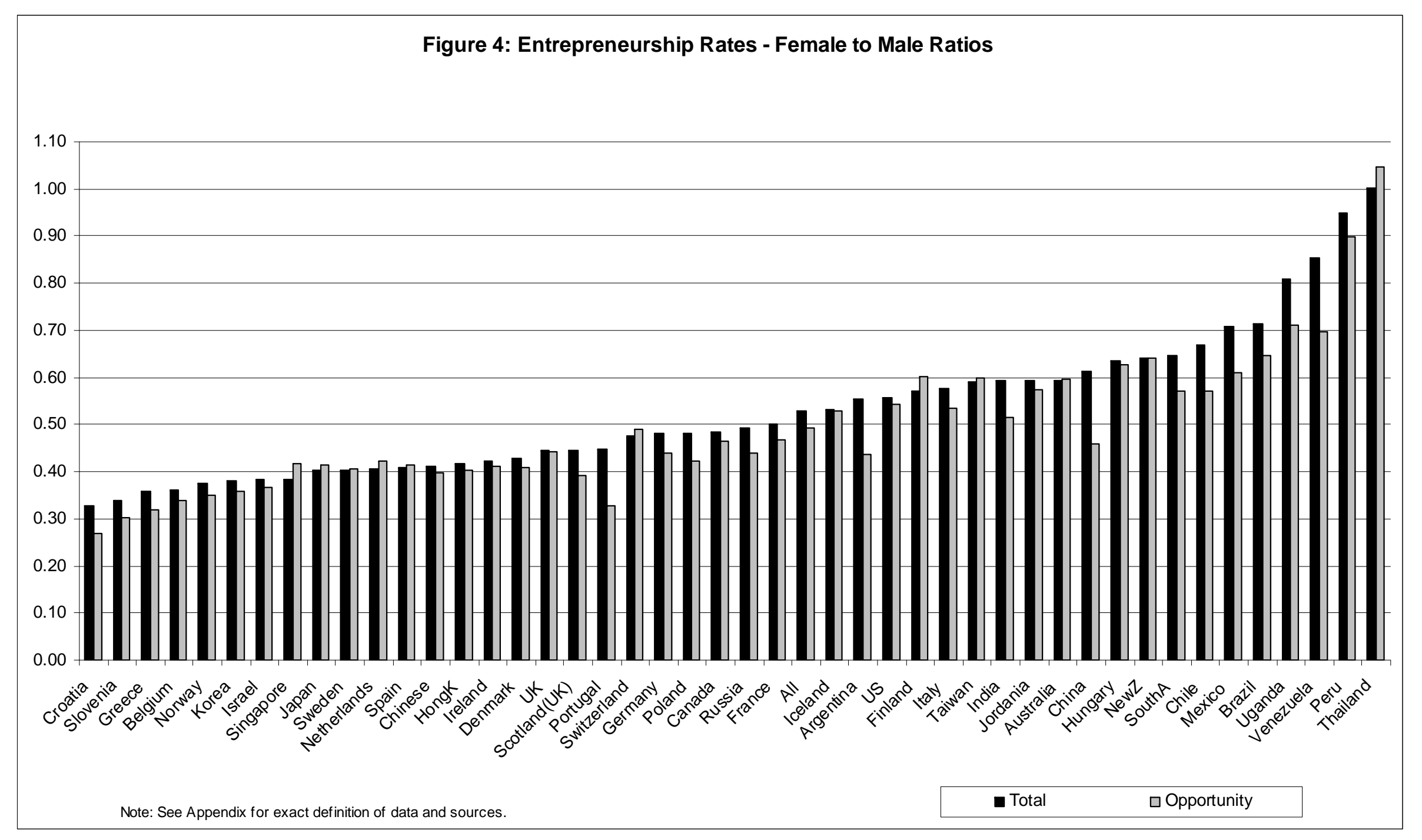



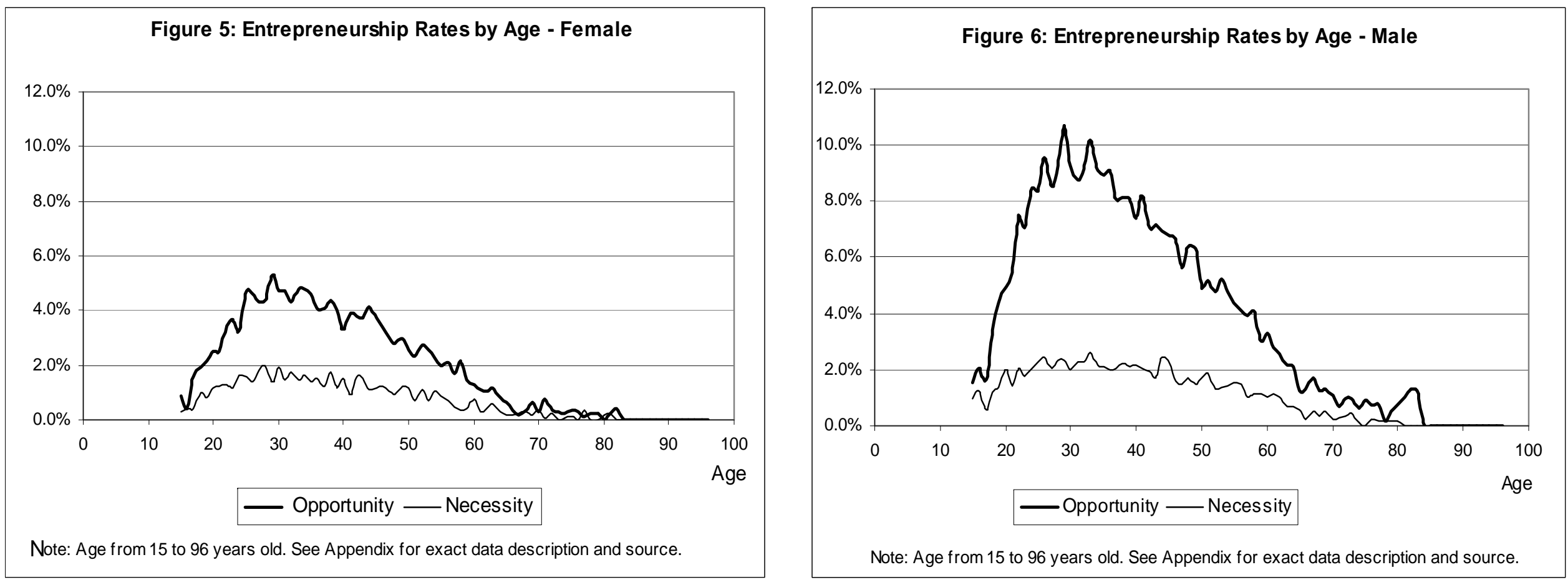

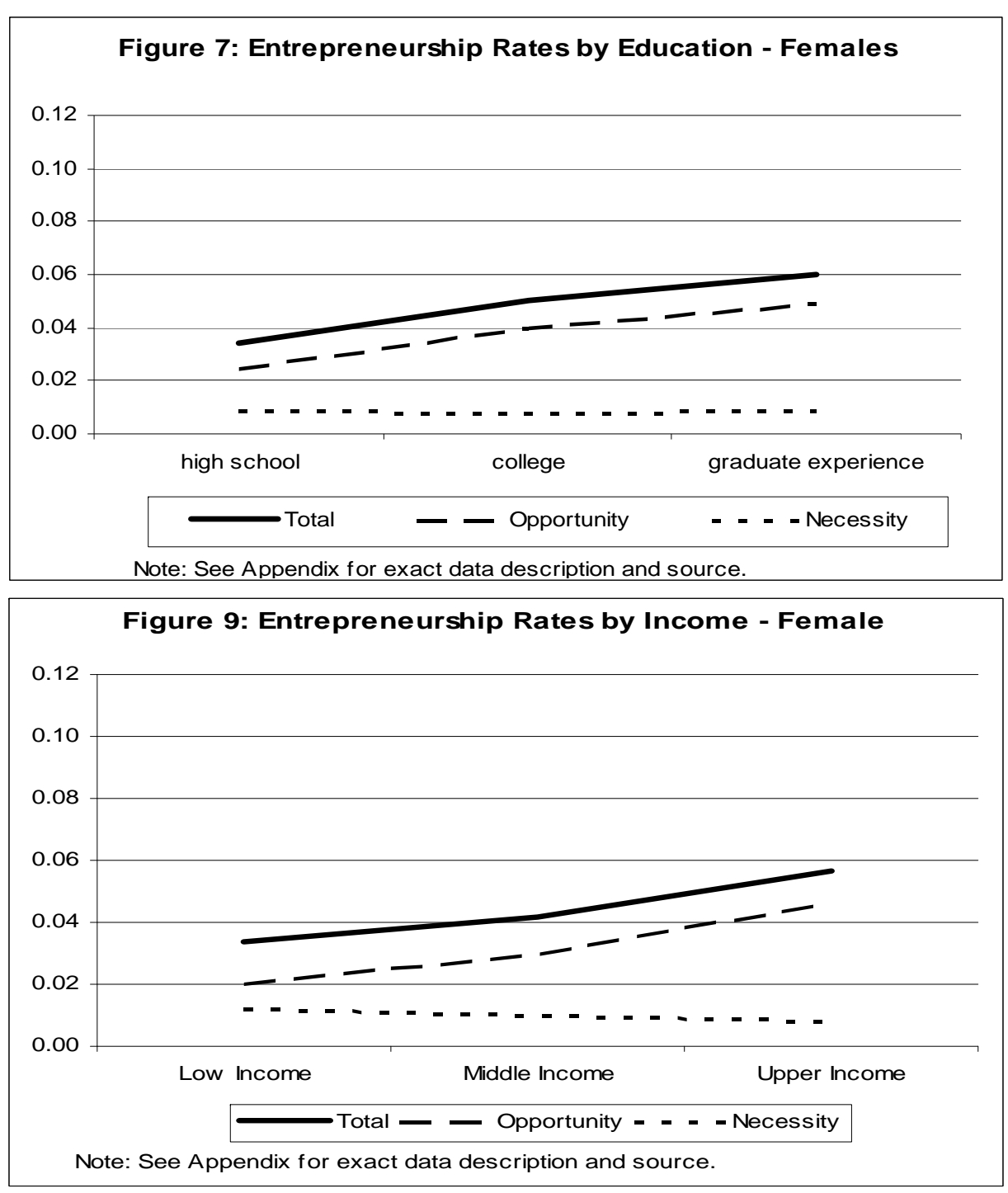

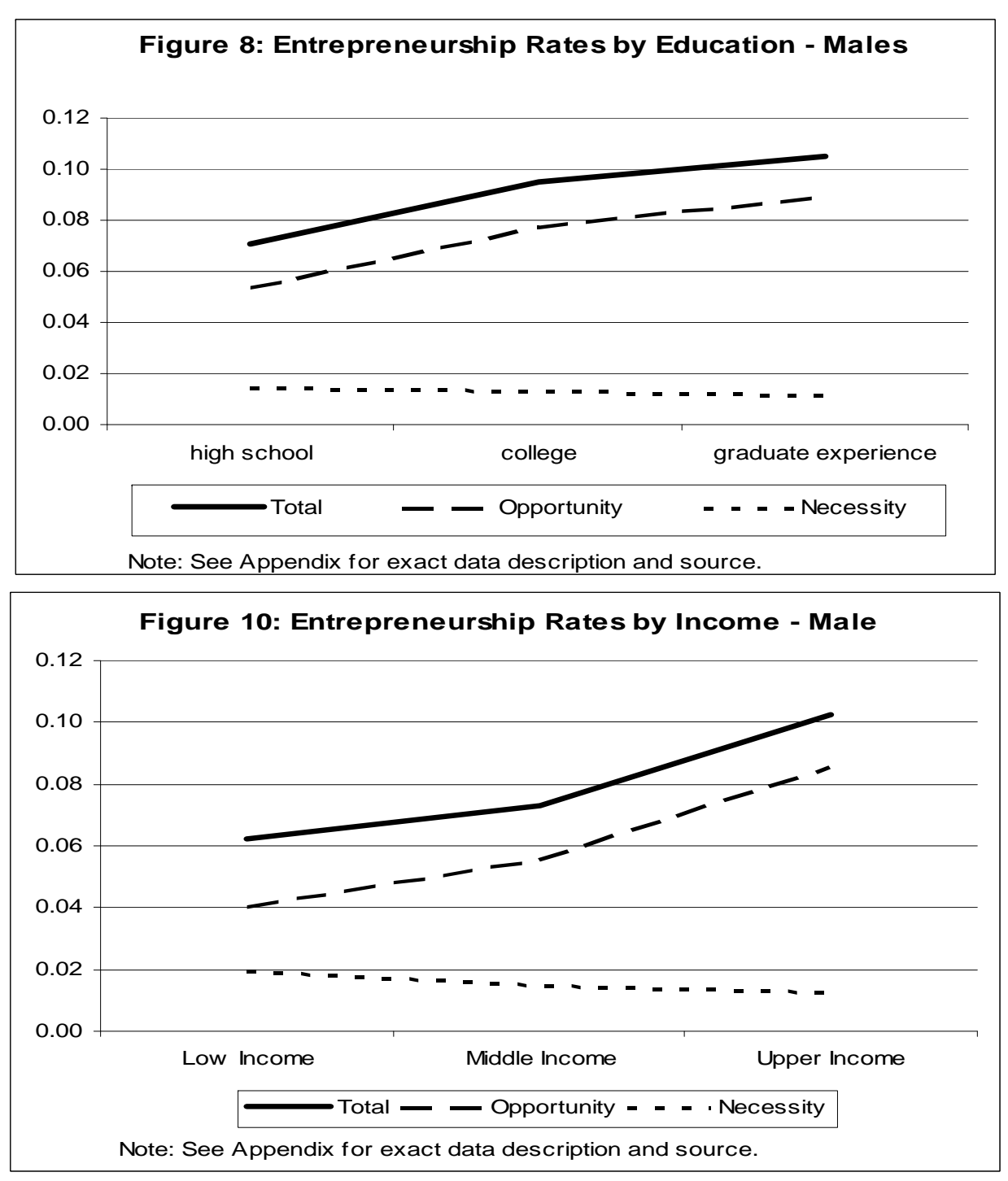

